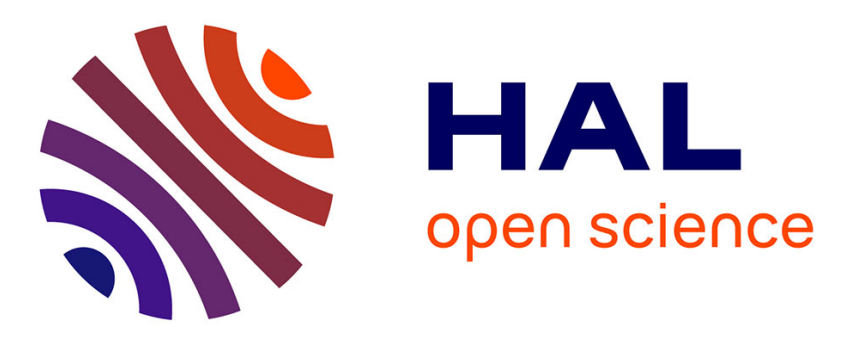

\title{
Immunization against GnRH in adult stallions: effects on semen characteristics, behaviour and shedding of equine arteritis virus
}

Dominik Burger, F. Janett, Marianne Vidament, R. Stump, D. Fortier, I. Imboden, R. Thun

\section{To cite this version:}

Dominik Burger, F. Janett, Marianne Vidament, R. Stump, D. Fortier, et al.. Immunization against $\mathrm{GnRH}$ in adult stallions: effects on semen characteristics, behaviour and shedding of equine arteritis virus. 9. International Symposium on Equine Reproduction, Aug 2006, Kerkrade, Netherlands. 10.1016/j.anireprosci.2006.03.098 . hal-02757682

\section{HAL Id: hal-02757682 \\ https://hal.inrae.fr/hal-02757682}

Submitted on 4 Jun 2020

HAL is a multi-disciplinary open access archive for the deposit and dissemination of scientific research documents, whether they are published or not. The documents may come from teaching and research institutions in France or abroad, or from public or private research centers.
L'archive ouverte pluridisciplinaire HAL, est destinée au dépôt et à la diffusion de documents scientifiques de niveau recherche, publiés ou non, émanant des établissements d'enseignement et de recherche français ou étrangers, des laboratoires publics ou privés. 


\title{
Immunization against GnRH in adult stallions: Effects on semen characteristics, behaviour and shedding of equine arteritis virus
}

\author{
D. Burger ${ }^{1}$, F. Janett ${ }^{2}$, M. Vidament ${ }^{3}$, R. Stump ${ }^{1}$, G. Fortier ${ }^{4}$, I. Imboden ${ }^{1}$ and R. Thun ${ }^{2}$
}

${ }^{1}$ National Stud Farm, Avenches, Switzerland, ${ }^{2}$ Clinic of Reproduction, University of Zürich, Switzerland, ${ }^{3}$ UMR INRA-CNRS-Université Tours-Haras Nationaux, Nouzilly, France,

${ }^{4}$ Laboratoire Départemental Frank Duncombe-Caen, France

\section{Introduction}

There are numerous indications for suppressing reproductive endocrine function in horses, the most frequent being the inhibition of undesirable sexual behaviour. Immunization against $\mathrm{GnRH}$ offers a viable alternative to surgical or hormonal castration by circumventing surgical

15risk, frequent drug administration and residue problems (Stout and Colenbrander, 2004; Stout, 2005). Furthermore, it may prove to be a therapeutic alternative for the treatment of equine arteritis virus (EAV) shedder stallions (Burger et al., 2004), as persistence of EAV in the accessory sex glands has been shown to be androgen dependent. Earlier studies examining $\mathrm{GnRH}$ vaccination in stallions have reported varied effects and do not allow a clear conclusion

20to be drawn. In the present study, 3 experiments were carried out to examine the effect of anti$\mathrm{GnRH}$ vaccination on semen characteristics, libido and shedding of equine arteritis virus in adult stallions.

\section{Materials and methods}

25

Experiment 1:

The experiment was carried out using 9 healthy Franches-Montagnes and Warmblood stallions (9-15 years) of proven fertility. The stallions were randomly allocated to a test group (6 stallions) and a control group (3 stallions). Ejaculates of all 9 stallions were collected and

30 examined weekly for 52 weeks. After the first semen collection, animals in the test group were immunized with $200 \mu \mathrm{g}$ of a GnRH-conjugate (Equity ${ }^{\circledR}$; CSL, Australia) intramuscularly in the neck. Control animals received saline solution. The treatment was repeated 4 and 12 weeks later. Side effects to the vaccination were recorded. Simultaneously to weekly semen collection, libido was evaluated (time elapsing between entering the stallion barn and erection

35 and ejaculation, respectively) and the number of mounts before ejaculation recorded. After ejaculation, scrotal width was measured using scrotal calipers. The volume, concentration, total sperm count and motility of the ejaculates were assessed and a morphological examination carried out. Blood samples were collected, always at the same time on the day of semen collection, and plasma testosterone concentration and $\mathrm{GnRH}$ antibody titre determined. 40

Experiment 2:

The effect of $\mathrm{GnRH}$ vaccination on libido, sexual behaviour and degree of distraction was evaluated in a retrospective questionnaire based field study, carried out with 22 stallions ( $7.4 \pm 4.3$ years old) of various breeds, vaccinated twice at an interval of 28 to 35 days. 18 stallions were vaccinated with $400 \mu \mathrm{g}$ of a $\mathrm{GnRH}$-conjugate (Improvac $\AA$; $\mathrm{CSL}$, Australia) intramuscularly and 4 stallions with Equity ${ }^{\circledR}$.

\section{Experiment 3:}

Four permanent EAV-shedding stallions aged 12 to 17 years were vaccinated twice 4 weeks

50 apart with either Improvac ${ }^{\circledR}$ (1 stallion) or Equity ${ }^{\circledR}$ (3 stallions). Semen was collected and virus content (cell culture and RT-PCR assay) was determined monthly for 6 months and then individually up to 15 months after first immunization. Additionally, 12 to 17 months after the first vaccination, two EAV seronegative mares where bred and serologically tested 4 weeks later. 


\section{Results}

\section{Experiment 1:}

Scrotal size, total sperm number, percentage of normal sperm and motility of all treated stallions continuously decreased after vaccination. Lowest mean motility values were recorded 606 months after the first immunization (Fig. 1). All the above parameters tended towards prevaccination levels 10 to 12 months after begin of the study. The decrease in libido was also significant but varied individually occuring between 13 and 18 weeks after the first vaccination and lasting between 10 to 32 weeks. While the decrease in one stallion was only slight, the remaining five showed gelding like behaviour. At the end of the experiment, 5 stallions

65regained their original libido but 1 stallion remained suppressed such that it was not possible to obtain an ejaculate until the end of the study.

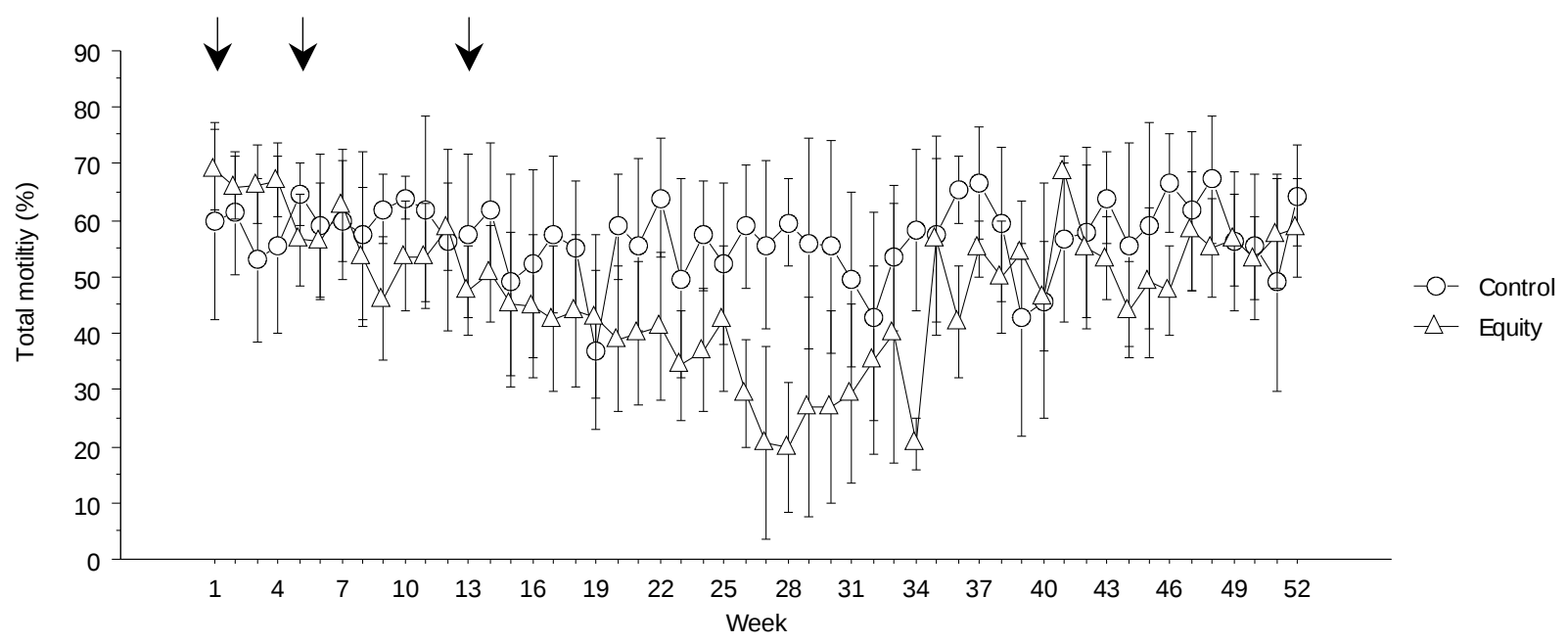

Fig.1. Mean ( \pm SEM) total motility in vaccinated and non vaccinated stallions. 70

Mean plasma testosterone concentrations in vaccinated stallions started to decrease significantly after the first injection and remained below $0.7 \mathrm{nmol} / \mathrm{L}$ plasma for 10 months (Fig. 2). By the end of the experiment, 3 stallions showed prevaccination levels ( $>1 \mathrm{nmol} / \mathrm{L}$ plasma) but 3 remained at a basal level.

75

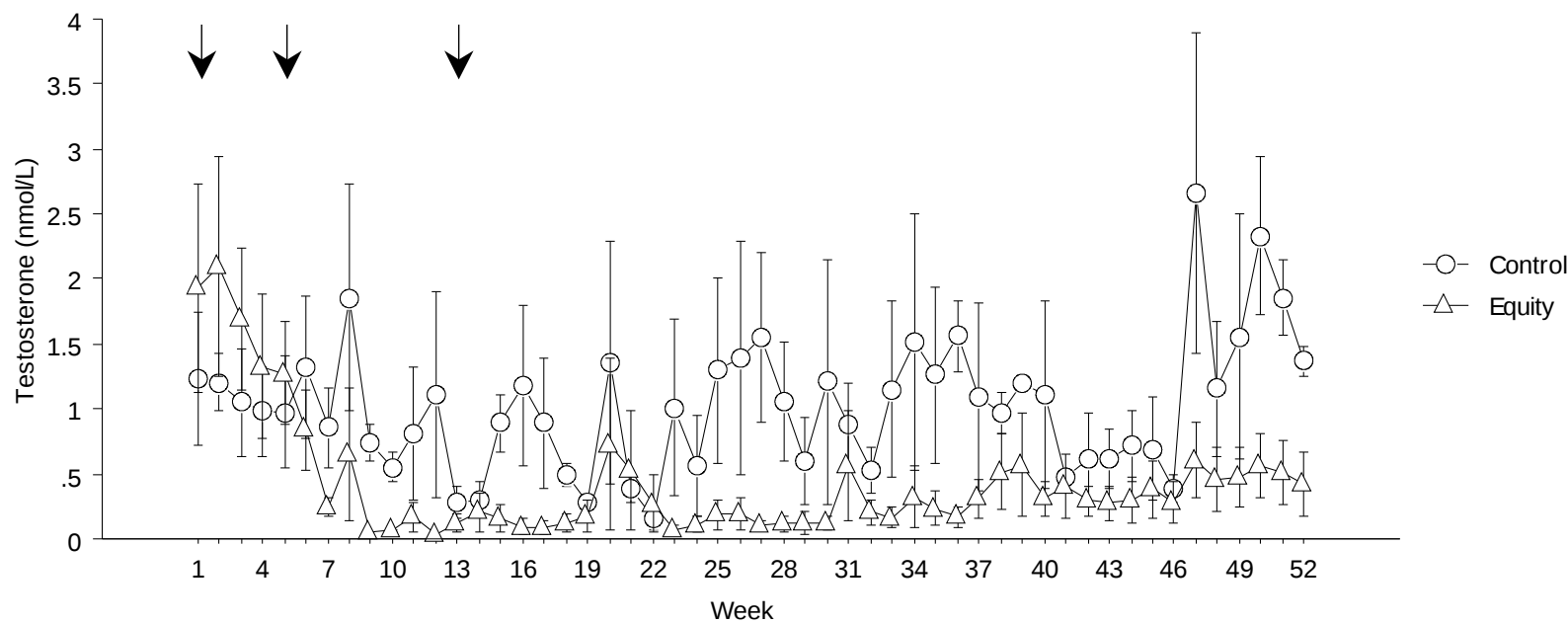


Fig. 2. Mean ( \pm SEM) plasma testosterone concentrations in vaccinated and non vaccinated stallions.

80Individual $\mathrm{GnRH}$ antibody titers peaked 2 months after the first immunization and remained high until the end of the study. Reactions to injection in the vaccinated group were few: 13 of the 18 vaccinations were without any side effects, the remainder showed mild to painful swellings at the injection site. No increases in body temperature $\left(>38^{\circ} \mathrm{C}\right)$ or other complications were observed.

85

\section{Experiment 2:}

Among the 19 stallions with a libido problem for the owner, 17 responded with the desired decrease in libido. Among the 15 stallions with a high distraction level, the owners reported less distraction in 13 stallions. Aggressiveness towards humans and/or other horses was 90markedly reduced in all 7 horses reported to be aggressive.

\section{Experiment 3:}

EAV could no longer be isolated from the semen of all four vaccinated stallions 4 - 6 months after the first immunization and from all subsequent semen collections. One stallion died for

95reasons not related to the study $6 \frac{1}{2}$ months after the first vaccination. The non-shedding, noncarrier status of the 3 remaining stallions was additionally confirmed by failure of each of the two mares to show seroconversion 28 days after breeding.

\section{Discussion}

100

The efficacy of GnRH vaccination appears to depend to a great extent on the type of vaccine used. Contrary to previous studies (Clement et al., 2005), the use of both Improvac $₫$ and Equity ${ }^{\circledR}$ has led to satisfactory results. More than $80 \%$ of the stallions in experiment 1 and 2 showed clear loss of libido, the duration of which varied greatly among single individuals.

105Similar observations regarding libido have also been reported after surgical castration of breeding stallions. This suggests that $\mathrm{GnRH}$ vaccination is a useful tool for temporary management of undesirable sexual behaviour in stallions.

Evaluation of semen characteristics in experiment 1 showed that although semen quality deteriorated, semen production was never entirely suppressed. At the end of the experiment,

110 all semen parameters were comparable to original values. The number and interval of booster vaccinations required for an optimal effect need further investigation. Failure of 3 stallions to reach plasma testosterone concentrations $>1 \mathrm{nmol} / \mathrm{L}$ in our study may be due to the third vaccination.

The GnRH antibody titres do not appear to be a useful indicator of immunization effect, either

115 on behaviour or on semen characteristics. 5 stallions showed a full return to reproductive function despite persistent antibody titres. The remaining stallion was surgically castrated 3 months after the study ended and histological examination of the testes revealed normal spermatogenesis.

All four treated EAV-shedding stallions were converted to a non-shedder status. In contrast to

120findings after short term treatment (35-38 days) with a GnRH antagonist (Fortier et al., 2002), no stallion in our study reverted to a shedding status. After failure of the two test mares to seroconvert, the stallions resumed breeding activity and showed normal fertility. For instance, stallion P (17 years at vaccination in July 2004, EAV shedder since 4 years) had pregnancy rates per cycle of $30 \%$ ( $n=30$ cycles) in 2004 and of $37 \%$ ( $n=38$ cycles) in 2005, respectively,

125 before and after vaccination. This study demonstrates that vaccination against GnRH could represent a promising method for successfully treating EAV-shedding breeding stallions.

\section{References}


130 1. Burger, D., Janett, F., Imboden, I., Zientara, S., Timoney, P., Thun, R., 2004. Treatment of an equine arteritis virus-shedding stallion by immunization against $\mathrm{GnRH}$. In: 15th International Congress on Animal Reproduction, vol.1, Porto Seguro, Brazil, 281 (Abstract). 2. Clement, F., Vidament, M., Daels, P., Van der Meer, F., Larry, J.L., Colenbrander, B., Turkstra, J., 2005. Immunocastration in stallions: Effect on spermatogenesis and

135 behaviour. Proceedings of the 4th International Symposium on Stallion Reproduction, Anim. Reprod. Sci. 89, 230-233 (Abstract).

3. Fortier,G., Vidament, M., DeCraene, F., Ferry, B., Daels, P.F., 2002. The effect of $\mathrm{GnRH}$ antagonist on testosterone secretion, spermatogenesis and viral excretion in EVAvirus excreting stallions. Theriogenology 58, 425-427.

140 4. Stout, T.A.E., 2005. Modulating reproductive activity in stallions: A review. Proceedings of the 4th International Symposium on Stallion Reproduction, Anim. Reprod. Sci. 89, 93103.

5. Stout, T.A.E., Colenbrander, B., 2004. Suppressing reproductive activity in horses using GnRH vaccines, antagonists or agonists. Anim. Reprod. Sci. 82-83, 633-643. 